\title{
Use of fatty acid methyl esters as Biocomponents for diesel fuels and for preparation of Cetane number improvers
}

\author{
Fahed Salem Khamis ${ }^{1}$, , Todor Vasilev Palichev², Galina Grigorova Khamis ${ }^{1}$, \\ Jabbar Lashkeri Ismail Agha ${ }^{3}$ \\ ${ }^{1}$ Department of Oil and Gas Technology, College of Oil and Minerals, Aden University, Ataq-Yemen \\ ${ }^{2}$ Department of industrial technology, Assen Zlatarov University, Burgas-Bulgaria \\ ${ }^{3}$ Department of Chemistry, College of science, Salahaddin University, Erbil-Iraq \\ Email address: \\ abumario@gmail.com (F. S. Khamis)
}

\section{To cite this article:}

Fahed Salem Khamis, Todor Vasilev Palichev, Galina Grigorova Khamis, Jabbar Lashkeri Ismail Agha. Use of Fatty Acid Methyl Esters as Biocomponents for Diesel Fuels and for Preparation of Cetane Number Improvers. American Journal of Chemical Engineering.

Vol. 1, No. 4, 2013, pp. 65-69. doi: 10.11648/j.ajche.20130104.11

\begin{abstract}
Up to $15 \%$ of fatty acid methyl esters (FAMEs) have been used as biocomponents for the manufacture of biodiesel fuels corresponding to the requirements of EN 590-09. Applying nitration with various agents has been obtained additives reducing the time delay of self-ignition (TDSI) of diesel fuels containing $20 \%$ light catalytic gas oil. The nitro products thus obtained increase also the resistance of the diesel fuel towards oxidation.
\end{abstract}

Keywords: Methyl Esters, Biodiesel, Nitration, Additives, Oxidation Stability

\section{Introduction}

Although the world-wide petroleum reserves are in front of future depletion fuel consumption increases. Simultaneously the exhaust emissions from conventional fuels deteriorate the environment and face us before an ecological disaster. As an urgent measure to combat environmental and energy crisis, the European Union adopted on 8 May 2003, Directive 30, which promotes the use and production of renewable fuels for transport biofuels, according to which the share of biofuels compared to petroleum-based fuels should reach $20 \%$ in 2020 .

Vegetable oils hold promise as alternative fuels for diesel engines. But their high viscosities, low volatilities and poor cold flow properties have led to the investigation of various derivatives. Fatty acid methyl esters known as Biodiesel, derived from triglycerides by transesterification with methanol have received the most attention [1].

Alternative diesel fuels are made from natural, renewable sources such as vegetable oil and fats [1]. The most commonly used oils for the production of Biodiesel are soybean [2], sunflower [3], palm [4], rapeseed [5], canola [6], cotton seed [7] and jatropha [8].

The use of additive allows reducing TDSI [9]. Moreover, additives that increase the cetane number not only provide better engine performance but also facilitate its start-up at lower temperatures and contribute to more complete fuel combustion $[9,10]$.

The scientific literature provides numerous organic compounds which in one way or another increase the selfignition of diesel fuel. Among them, compounds containing nitrogen and oxygen $[9,10]$ have been most widely used.

The aims of the present work were

- To study of the possibility for use of FAMEs as a component in the production of biodiesel fuel.

- Synthesis of additives by nitration of FAMEs with various agents with the purpose of reducing the TDSI of diesel fuel containing $20 \%$ light catalytic gas oil.

\section{Materials and Methods}

Fatty acids (FAs) obtained as waste product in production of sunflower oil were used as feedstock. In order to remove the undesirable impurities, the same were subjected in advance to vacuum distillation in the temperature range from 95 to $250^{\circ} \mathrm{C}$ and at a residual pressure of $15 \mathrm{hPa}$. The mixture of FAs was analyzed by chromatograph using the methodology of Cert [11]. The 
chromatographic analysis of the FAs mixture demonstrated in Table 1 shows that the sunflower oil contains mainly unsaturated carboxylic acids, namely Linoleic and Oleic acids, with a total content of $85.3 \%$.

The saturated carboxylic acids are represented mainly by Palmitic acid $-8.9 \%$ and Stearic acid $-5.1 \%$, while the total content of Arachidic and Myristic acid is less than $1 \%$.

Table 1. Chromatographic analysis of the mixture of fatty acids

\begin{tabular}{ll}
\hline Acids & Content, \% \\
\hline Linoleic acid (9Z,12Z-octadecadienoic acid) & 64,8 \\
Oleic acid (9Z-octadecenoic acid) & 20,5 \\
Palmitic acid (hexadecanoic acid) & 8,9 \\
Stearic acid (octadecanoic acid) & 5,1 \\
Arachidic acid (eicosanoic acid) & - \\
Myristic acid (tetradecanoic acid) & 0,7 \\
\hline
\end{tabular}

The esterification of the FAs mixture was carried out according to the method of Aluyor [12] and the characteristics of the feedstock and of the obtained FAMEs is pointed in Table 2. As it is seen from the data in Table 2, the acid number of the mixture decreases from 195.73 to $0,46 \mathrm{mg} \mathrm{KOH} / \mathrm{g}$, and the kinematic viscosity measured at 50 and $100^{\circ} \mathrm{C}$ decreases from 10.24 and 3.41 to 2.52 and $1.04 \mathrm{~mm}^{2} / \mathrm{s}$, respectively which is an evidence of the successful performance of the esterification process.

Table 2. Characteristics of the raw material, of fatty acids mixture after vacuum distillation and of the obtained methyl esters

\begin{tabular}{llll}
\hline Indices & $\begin{array}{l}\text { Raw } \\
\text { material }\end{array}$ & $\begin{array}{l}\text { Mixture } \\
\text { Fas }\end{array}$ & FAMEs \\
\hline Density at $20^{\circ} \mathrm{C}, \mathrm{kg} / \mathrm{m}^{3}$ & 904.4 & 890.8 & 874.7 \\
Kinematic viscosity, $\mathrm{mm}^{2} / \mathrm{s}$ & & & \\
- at $50^{\circ} \mathrm{C}$ & 13.31 & 10.24 & 2.52 \\
- at $100^{\circ} \mathrm{C}$ & 3.92 & 3.41 & 1.04 \\
Refractive index, $\boldsymbol{n}_{\boldsymbol{D}}^{\mathbf{2 0}}$ & 1.4727 & 1.4680 & 1.4582 \\
Iodine number, $\mathrm{g} \mathrm{I} / 100 \mathrm{~g}$ & 130.57 & 134.92 & 132.03 \\
Acid number, $\mathrm{mg} \mathrm{KOH} / \mathrm{g}$ & 196.16 & 195.73 & 0.46 \\
Element composition, $\%$ & & & \\
- carbon & - & 76.84 & 77.28 \\
- hydrogen & - & 11.68 & 11.87 \\
- oxygen & - & 11.48 & 10.85 \\
\hline
\end{tabular}

In order to prove the character of the proceeding processes during esterification the IR spectra of the purified FAs and of the obtained FAMEs were recorded Fig. 1.

The spectral analysis was performed in the range within $600-3600 \mathrm{~cm}^{-1}$. In the IR-the spectrum of the feedstock are observed bands for the characteristic oscillations of aliphatic carboxylic acids - a wide plateau is observed at $3600-2400 \mathrm{~cm}^{-1}$ corresponding to the their dimeric structure.
Fig. 1 also shows that this plateau in the spectrum of the mixture of FAMEs narrows, which is an indication of loss of the carboxyl group. The valence vibrations of hydroxyl group bonded in the carboxyl at $900-1000 \mathrm{~cm}^{-1}$ disappear and at $1720 \mathrm{~cm}^{-1}$ is observed an intense peak, characteristic of valence oscillation of the bond $v(\mathrm{C}=\mathrm{O})$ in the ester group.

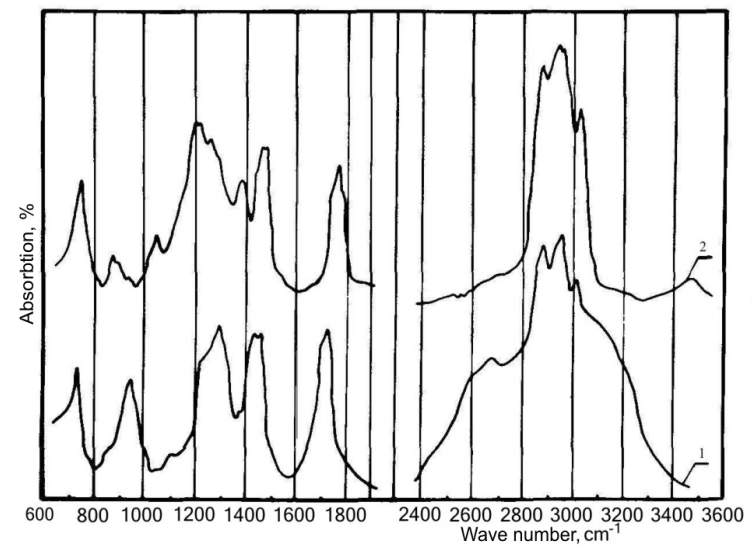

Fig 1. IR spectra of fatty acid (1) and fatty acid methyl ester (2)

In order to accomplish the second task we have carried a modification of the obtained FAMEs using different nitrating agents - dilute nitric acid, aluminum nitrate nanohydrate and nitrogen oxides. The conditions under which the modification of FAMEs was conducted are indicated in Table 4. Experiments were carried out with diesel fuel containing 20\% catalytic gas oil.

\section{Results and Discussion}

For the purpose of the first object of the research, namely the use of FAMEs as biocomponents in the production of diesel fuel we have prepared and investigated samples containing 5, 10 and 15 vol. \% esters. The study on the physicochemical characteristics of the base petroleumderived diesel fuel and of the obtained samples was performed according to the regulations of EN 590-09.

The results reported in Table 3 show that fuels containing up to $15 \%$ vol. FAMEs meet the requirements of EN 590 09 for diesel fuels.

Cetane number and cetane index increase, indicating that the resulting fuels have better self-ignition characteristics. FAMEs exert also positive effect on lubricity.

Increase in the quantity of FAMEs, however, deteriorates the low-temperature properties of the base diesel fuel increasing the percentage of FAMEs increases the coldfilter plugging point of the fuel. However, samples containing 10 and $15 \%$ vol. FAMEs could be attributed to Class "D" and "E". It is also observed a substantial increase in the temperature at which $95 \%$ of the fuel distilled, while for the fuel containing $15 \%$ of esters this indicator is on the limit of the requirements of the standard. All three samples do not show increased corrosion aggressiveness. 
The studies show that FAMEs affect negatively those indicators which characterize the chemical stability of the fuel and its tendency to soot formation. The amounts of coke residue of the $10 \%$ distillation residue and of the insoluble products of oxidation are near to the limits of the standard requirements Table 3 . These results are related to the fact that the majority of FAs are unsaturated. Therefore our further our studies will continue on the basis of hydrogenation of the resulting mixture of FAMEs.

Table 3. Characteristics of the diesel fuels obtained by mixing of base diesel fuel with fatty acid methyl esters

\begin{tabular}{|c|c|c|c|c|c|c|}
\hline \multirow{3}{*}{ Index } & \multirow{3}{*}{ Test methods } & & \multirow{3}{*}{$\begin{array}{l}\text { Standard } \\
\text { value }\end{array}$} \\
\hline & & \multirow{2}{*}{ Base diesel fuel } & \multicolumn{2}{|c|}{ Amount of FAMEs } & \multirow[b]{2}{*}{$15 \%$ vol } & \\
\hline & & & 5\%vol & $10 \%$ vol & & \\
\hline Cetane index & EN ISO 4264 & 50.5 & 51.0 & 51.4 & 52.0 & $\min 40$ \\
\hline PAH, \% wt & EN ISO12916 & 6.43 & 6.10 & 5.78 & 5.46 & $\max 11$ \\
\hline Flash point, ${ }^{\circ} \mathrm{C}$ & EN ISO 22719 & 75 & 76 & 78 & 80 & $\min 55$ \\
\hline $\begin{array}{l}\text { Carbon residue (on } 10 \% \text { distillation } \\
\text { residue), } \% \mathrm{wt}\end{array}$ & EN ISO 10370 & 0.010 & 0.085 & 0.171 & 0.289 & $\max 0.30$ \\
\hline Ash content, $\% \mathrm{wt}$ & EN ISO 6245 & 0.001 & 0.001 & 0.001 & 0.001 & $\max 0.01$ \\
\hline Copper strip corrosion $\left(3 \mathrm{~h} @ 50^{\circ} \mathrm{C}\right)$, class & EN ISO 2160 & 1 & 1 & 1 & 1 & Class 1 \\
\hline Viscosity at $40^{\circ} \mathrm{C}, \mathrm{mm}^{2} / \mathrm{s}$ & EN ISO 3104 & 2.55 & 3.28 & 3.72 & 4.39 & $2.0-4.5$ \\
\hline Water content, $\mathrm{mg} / \mathrm{kg}$ & EN ISO 12937 & 98.8 & 104.6 & 111.2 & 118.3 & $\max 200$ \\
\hline Distillation recovered, $\% \mathrm{~V} / \mathrm{V}$, at: & EN ISO 3405 & & & & & \\
\hline$-250^{\circ} \mathrm{C}$ & & 42.5 & 41.3 & 39.9 & 38.2 & ? 65 \\
\hline$-350^{\circ} \mathrm{C}$ & & 97.0 & 96.0 & 94.8 & 93.2 & ? 85 \\
\hline $95 \%(\mathrm{~V} / \mathrm{V})$ recovered at, ${ }^{\circ} \mathrm{C}$ & & 340 & 346 & 351 & 355 & 360 \\
\hline Cold filter plugging point & EN 116 & & & & & \\
\hline - Class D, ${ }^{\circ} \mathrm{C}$ & & - & - & -13 & -10 & \\
\hline - Class E, ${ }^{\circ} \mathrm{C}$ & & -19 & -16 & - & - & \\
\hline Density at $15{ }^{\circ} \mathrm{C}, \mathrm{kg} / \mathrm{m}^{3}$ & EN ISO 3675 & 836.7 & 836.7 & 837.8 & 839.4 & $820-845$ \\
\hline Sulphur content, ppm & EN, ISO 20846 & 8.9 & 8.9 & 8.6. & 8.4 & $\max 10$ \\
\hline Total contamination, $\mathrm{mg} / \mathrm{kg}$ & EN 12662 & 4.3 & 4.3 & 4.3 & 4.2 & $\max 24$ \\
\hline $\begin{array}{l}\text { Lubricity, corrected WSD } 1.4 \text { at } 60^{\circ} \mathrm{C} \text {, } \\
\mu \mathrm{m}\end{array}$ & ISO $12156-1$ & 360 & 360 & 348 & 332 & $\max 460$ \\
\hline Cetane number & EN ISO 5165 & 52 & 52 & 53 & 54 & $\min 51$ \\
\hline Oxidation stability, $\mathrm{g} / \mathrm{m}^{3}$ & EN ISO 12205 & 12 & 12 & 17 & 21 & $\max 25$ \\
\hline
\end{tabular}

Bench tests of the obtained fuels were conducted on a fuel installation (ITD-69) and their cetane number was determined. The results showed that fuels containing up to $15 \%$ vol. FAMEs have good starting and operation properties. At the same time it is found that by increasing the quantity of the used methyl esters over $10 \%$ vol. appears noticeably increased deposits on valves and of resins on the sprayer nozzle, which require additional use of additives possessing antioxidant, dispersing and detergent properties.

For the purposes of the second task, i. e. synthesis of additives that reduce the TDSI, the obtained methyl esters were subjected to nitration. However, it was found that the use of the pointed above nitrating agents did not lead to the obtaining of products suitable for additives due to their poor solubility in diesel fuel. The most suitable conditions for the nitration of FAMEs - molar ratio of raw material and nitrating agent, temperature and time of the reaction are shown in Table 4.

At nitration with nitric acid, the optimum contact time was four hours since at shorter contact time the rates of nitration is very low, and for a longer contact time are obtained products which are partially or completely insoluble in middle distillate fuels, and the solubility decreases with increasing acid concentration. From the data in Table 4 it is seen that an increase in the acid concentration from 15 to $25 \%$ at the same time of contact are obtained products with a high content of bound nitrogen.

Table 4. Conditions of fatty acid methyl esters modification

\begin{tabular}{|c|c|c|c|c|}
\hline \multirow[b]{2}{*}{$\begin{array}{l}\text { Sample } \\
\text { № }\end{array}$} & \multirow[b]{2}{*}{ Nitrating agent } & \multicolumn{3}{|c|}{ Nitration conditions } \\
\hline & & $\begin{array}{l}\text { Molar ratio } \\
\text { raw material: } \\
\text { nitrating agent }\end{array}$ & $\begin{array}{l}\text { Tempe } \\
\text { rature, } \\
{ }^{\circ} \mathrm{C}\end{array}$ & $\begin{array}{l}\text { Contact } \\
\text { time, } \mathbf{h}\end{array}$ \\
\hline 1 & $15 \% \mathrm{HNO}_{3}$ & $1: 1.5$ & 90 & 4 \\
\hline 2 & $15 \% \mathrm{HNO}_{3}$ & $1: 1.5$ & 90 & 6 \\
\hline 3 & $25 \% \mathrm{HNO}_{3}$ & $1: 1.5$ & 90 & 4 \\
\hline 4 & $25 \% \mathrm{HNO}_{3}$ & $1: 1.5$ & 90 & 6 \\
\hline 5 & $\mathrm{Al}\left(\mathrm{NO}_{3}\right)_{3} .9 \mathrm{H}_{2} \mathrm{O}$ & $1: 1$ & 95 & 4 \\
\hline 6 & $\mathrm{Al}\left(\mathrm{NO}_{3}\right)_{3} .9 \mathrm{H}_{2} \mathrm{O}$ & $1: 1$ & 95 & 6 \\
\hline 7 & $\mathrm{Al}\left(\mathrm{NO}_{3}\right)_{3} \cdot 9 \mathrm{H}_{2} \mathrm{O}$ & $1: 2$ & 95 & 4 \\
\hline 8 & $\mathrm{Al}\left(\mathrm{NO}_{3}\right)_{3} \cdot 9 \mathrm{H}_{2} \mathrm{O}$ & $1: 2$ & 95 & 6 \\
\hline 9 & Nitrogen oxides & - & 50 & 2 \\
\hline 10 & Nitrogen oxides & - & 70 & 2 \\
\hline
\end{tabular}


In the case of aluminum nitrate nanohydrate as nitrating agent, best results are obtained with a contact time of 6 hours and a molar ratio of the raw material: nitrating agent of $1: 2$. Products obtained under these conditions are with a high content of bound nitrogen and are completely soluble in middle distillate fractions, which make them appropriate to be investigated as additives for diesel fuels. The most efficient is the nitration with nitrogen oxides, and in this case are obtained products with the highest content of nitrogen and highest iodine number. Furthermore, all the products are completely soluble in diesel fuel.

The results in Table 5 show that the oxygen content and acid number in the obtained products are in direct dependence both on the contact time and on the type and amount of the nitrating agent.

Table 5. Characteristics of the obtained products after fatty acid methyl esters nitration

\begin{tabular}{|c|c|c|c|c|c|c|}
\hline \multirow{2}{*}{$\begin{array}{l}\text { Sample } \\
\text { № }\end{array}$} & \multicolumn{4}{|c|}{ Element composition } & \multirow{2}{*}{$\begin{array}{c}\text { Acid } \\
\text { number, } \\
\text { mg KOH/g }\end{array}$} & \multirow{2}{*}{$\begin{array}{c}\text { Iodine } \\
\text { number, } \\
\text { gI }_{2} / \mathbf{1 0 0 g}\end{array}$} \\
\hline & $\mathbf{C}$ & $\mathbf{H}$ & $\mathbf{O}$ & $\mathbf{N}$ & & \\
\hline 1 & 68.72 & 10.30 & 19.15 & 1.83 & 6.72 & 40.32 \\
\hline 2 & 59.00 & 9.10 & 28.10 & 3.80 & 22.60 & 35.06 \\
\hline 3 & 65.50 & 9.70 & 22.40 & 2.40 & 8.75 & 35.13 \\
\hline 4 & 54.70 & 8.40 & 32.60 & 4.30 & 26.21 & 29.07 \\
\hline 5 & 73.45 & 12.29 & 13.46 & 0.80 & 3.36 & 72.89 \\
\hline 6 & 64.41 & 11.06 & 20.39 & 4.14 & 6.42 & 20.83 \\
\hline 7 & 73.21 & 11.48 & 14.11 & 1.20 & 6.73 & 67.31 \\
\hline 8 & 60.22 & 9.58 & 24.84 & 5.36 & 10.84 & 13.22 \\
\hline 9 & 70.66 & 9.20 & 16.40 & 3.72 & 5.42 & 15.23 \\
\hline 10 & 62.28 & 8.95 & 22.25 & 6.57 & 8.20 & 9.61 \\
\hline
\end{tabular}

Table 6. Effect of additive on the cetane number and oxidation stability of the blended diesel fuel

\begin{tabular}{llll}
\hline $\begin{array}{l}\text { Sample } \\
\text { number }\end{array}$ & $\begin{array}{l}\text { Type and amount } \\
\text { of the additive }\end{array}$ & $\begin{array}{l}\text { Cetane } \\
\text { number }\end{array}$ & $\begin{array}{c}\text { Results for: } \\
\text { Oxidation } \\
\text { stability, } \mathbf{g} / \mathbf{m}^{3}\end{array}$ \\
\hline 1 & - & 47 & 29.8 \\
2 & $0.05 \%$ ECA-8478 & 50 & 23.9 \\
3 & $0.15 \%$ ECA-8478 & 52 & 23.6 \\
4 & $0.20 \%$ ECA-8478 & 53 & 23.2 \\
5 & $0.05 \%$ sample.6 & 49 & 23.5 \\
6 & $0.10 \%$ sample. 6 & 50 & 22.4 \\
7 & $0.20 \%$ sample. 6 & 51 & 21.2 \\
8 & $0.05 \%$ sample. 8 & 50 & 23.1 \\
9 & $0.10 \%$ sample. 8 & 51 & 22.2 \\
10 & $0.20 \%$ sample. 8 & 52 & 21.1 \\
11 & $0.05 \%$ sample. 9 & 50 & 22.9 \\
12 & $0.10 \%$ sample. 9 & 52 & 21.8 \\
13 & $0.20 \%$ sample. 9 & 53 & 20.7 \\
14 & $0.05 \%$ sample. 10 & 51 & 22.3 \\
15 & $0.10 \%$ sample. 10 & 53 & 21.1 \\
\hline & $0.20 \%$ sample. 10 & 54 & \\
\hline
\end{tabular}

At approximately the same nitrogen content the products obtained by nitration with nitric acid are with the highest oxygen content and acid value. Thus, in this case oxidation processes also take place.

The products resulting from the modification of FAMEs were tested as additives for diesel fuels in order to reduce the TDSI. The results of the research are presented in Table 6.

The efficiency of these products as additives for reducing the TDSI was studied and compared with commercial additive ECA-8478, which is based on aliphatic nitro derivatives.

Of the synthesized products samples 6, 8, 9 and 10 were used. As already mentioned, they contain the same functional groups, but are prepared by nitration with various nitrating agents and under different conditions and, therefore, have different content of bound nitrogen, acid and iodine number Table 5. The starting fuel and the samples containing additives were characterized according to the requirements of EN 590-09 and it has been found that the additives have a major impact only on the cetane number and oxidation stability. The fuel containing up to $0.2 \%$ of sample 10 is characterized by the highest oxidation stability.

The results in Table 6 reveal that the efficiency of the synthesized by us additives with respect to the cetane number of the diesel fuel with $20 \%$ light catalytic gas oil is identical to that of the stock additive. The value of the cetane number depends on the type of the additive, i.e. on the conditions of its preparation due to major importance of the amount of bound nitrogen. The highest increase in cetane number is demonstrated by the additive in sample 10 , which in amount of $0.10 \%$ increases the cetane number by 6 points.

\section{Conclusions}

1. It was found that FAMEs improve the self-ignition and lubricating properties of the diesel fuel.

2. It was established that the fuels containing FAMEs have lower oxidation stability, greater tendency to deposits formation and poorer low-temperature properties.

3. It was found that diesel fuels containing up to $15 \%$ vol. FAMEs meet the requirements of the standard for diesel fuel.

4. It was found that at the nitration of FAMEs are obtained nitro products which reduce the TDSI, i.e. improve cetane number of diesel fuel.

5. It was shown that the highest efficiency is demonstrated by the product obtained at nitration at a temperature of $70^{\circ} \mathrm{C}$ and duration of 2 hours. This product in amount of $0.10 \%$ increases cetane number by 6 points.

6 . It was found that the obtained nitro products enhance the oxidation stability of the diesel fuel. 


\section{References}

[1] S.P. Singh and Dipti Singh, "Biodiesel production through the different sources and their esters as the substitute of diesel: A review," Renewable and sustainable energy reviews, vol. 14, pp. 200-216, 2010.

[2] H. Noureddini and D. Zhu, "Kinetics of transesterification of soybean oil," J Am Oil Chem Soc, vol. 74, pp. 1457-1463, 1997.

[3] M. Mohamed, B. Soumanoua, T. Uwe and A. Bornscheuer, "Improvement in lipasecatalyzed synthesis of fatty acid methyl esters from sunflower oil," Enzyme Microb Technol, vol. 33, pp. 97-103, 2003.

[4] D. Darnoko and M. Cheryan, "kinetics of palm oil transesterrification in a batch reactor," J Am oil chem soc, vol. 77(12), pp. 1263-1267, 2000.

[5] D. Kusdiana and S. Saka, "kinetics of transestrification in rapseed oil to biodiesel fuel as tested in supercritical methanol, " Fuel, vol.80, pp. 693-5, 2001.

[6] L. Zou and S. Atkinson, "Characterising vehicle emissions

from the burning of biodiesel made from vegetable oil," Environ technol, vol. 24, pp. 1253-1260, 2003.

[7] Ö. Köse, M. Tüter and HA. Aksoy, "Immobilized candida Antarctica lipase-catalyzed alcoholysis of cotton seed oil in a solvent-free medium," Bioresour technol, vol. 83, pp. 125$129,2002$.

[8] N. Foidl, G. Foidl, M. Sanchez, M. Mittelbach and S. Hackel, "Jatropha curcas L. as a source for the production of biofuel in Nicaragua," Bioresour Technol, vol. 58, pp. 77-82, 1996.

[9] A. Gureev, V. Azev and G. Kamfer, "Topliv dlia dizelaj, svoistva I primenenie,” Himia, Moscow, 1993, pp. 106-153.

[10] G. L. Suppes, Zhi Chen, Ying Rui, M. Mason and J.A. Heppert, "Synthesis and cetane improver performance of fatty acid glycol nitrates, " Fuel, vol. 78, 1, pp. 73-81, 1999.

[11] A. Cert, W. Moreda and C. Perez, "Chromatographic analysis of minor constituents in vegetable oils," Chromatogr., vol. A 881, pp 131-148, 2000.

[12] E. O. Aluyor, C. E. Ozigagu, O. I. Oboh and P. Aluyor, "Chromatographic analysis of vegetable oils: A review," Scientific Research and Essay, Vol. 4 (4), pp 191-197, April, 2009. 